\title{
Transatlantica
}

Revue d'études américaines. American Studies Journal

\section{Looking into the attribute of transcendent genius: George Henry Boker and Robert Conrad's use of Shakespeare}

\section{Ronan Ludot-Vlasak}

\section{(2) OpenEdition \\ Journals}

Édition électronique

URL : https://journals.openedition.org/transatlantica/4889

DOI : 10.4000/transatlantica.4889

ISSN : $1765-2766$

Éditeur

Association française d'Etudes Américaines (AFEA)

Référence électronique

Ronan Ludot-Vlasak, « Looking into the attribute of transcendent genius: George Henry Boker and Robert Conrad's use of Shakespeare », Transatlantica [En ligne], 1 | 2010, mis en ligne le 16 juillet 2010, consulté le 10 février 2023. URL : http://journals.openedition.org/transatlantica/4889 ; DOl : https:// doi.org/10.4000/transatlantica.4889

Ce document a été généré automatiquement le 10 février 2023.

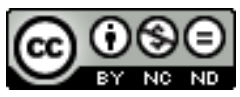

Creative Commons - Attribution - Pas d'Utilisation Commerciale - Pas de Modification 4.0 International - CC BY-NC-ND 4.0

https://creativecommons.org/licenses/by-nc-nd/4.0/ 


\title{
Looking into the attribute of transcendent genius: George Henry Boker and Robert Conrad's use of Shakespeare
}

\author{
Ronan Ludot-Vlasak
}

1 The overwhelming majority of nineteenth-century American plays have now fallen into oblivion. They are often regarded as a form of low culture and their interest is generally considered to be purely documentary. Even at the time they were produced, many writers and reviewers were extremely critical of the American theatre and of the vulgarity of its audience (Moses, Brown 40-43, 70-71). Yet drama was one of the most popular forms of entertainment, and although they did not necessarily go to the same theatres, all social classes regularly attended dramatic performances. Productions were not always restricted to theatres: churches, steamboats or museums were also used as theatrical venues (Ackerman xvi). Rosemarie K. Bank has shown that a "theatre culture" spread in American society throughout the nineteenth century, as exemplified by the following "cultural performances": the return of General La Fayette to America or the opening of the Erie Canal (Bank 3,5). The theatre also raised major political issues. Not only did plays address political subjects (tyranny, monarchy, the American Revolution, political virtue, to mention the most obvious ones), but theatrical life itself also revealed some of the social, cultural and ideological tensions of mid-nineteenthcentury America. This led to several riots, the most violent one being the Astor Place riot in $1849^{1}$.

2 While the better part of American dramatists of that period advocated the development of a national drama, Shakespeare remained one of the most produced playwrights throughout the nineteenth century, as the index of plays performed in major cities all across America shows (Dunn 171-172). Kim Sturgess, Michael Bristol and Lawrence Levine have analysed how social practices and a complex ideological apparatus enabled Americans to capture the works and the figure of the man who had become the greatest 
symbol of the English genius by the end of the eighteenth century: as America was progressively "shakespearised," Shakespeare himself was Americanised ${ }^{2}$.

American dramatists had to face a double challenge. They had to create an American drama that would not be a mere imitation of European models while properly addressing the works and the figure of the Elizabethan playwright. This article explores three mid-nineteenth-century American plays which reveal the literary responses of two American playwrights to Shakespeare: Robert Conrad (1810-1848) and George Henry Boker (1823-1890). In Jack Cade, Conrad focused on a fifteenth-century rebellion that is dramatised in the fourth act of Shakespeare's 2 Henry VI. Although Anne Boleyn heavily relies on Shakespearean lines and archetypes, Boker's treatment of Henry VIII's reign in this historical play is the exact opposite of Shakespeare's vision, and Francesca da Rimini is a Romantic tragedy pervaded with references to his works. Those two Democratic dramatists are emblematic of a double trend which characterised nineteenth-century American drama. While Conrad advocated a clear ideological break from European models, Boker tried to combine Americanness and a form of filiation with European aesthetic and literary traditions.

4 Literary recycling may be accounted for both in terms of continuity and discontinuity, as it aims at reconfiguring a literary material for new use ("the living transmission of an innovation always capable of being reactivated," Ricoeur 68) and is thus informed by "the dialectic of presence and absence" (Bloom 2003 71). My contention is that Boker and Conrad's responses did not enable the two authors to reinvent the works of their predecessor, for they failed to challenge Shakespeare as "the one unassailable icon for a cultural tradition" as well as "the normative force" of the Elizabethan playwright (Bristol 15, 38).

5 Jack Cade, which was awarded the Forrest Prize in 1841, is Robert Conrad's most famous dramatic work and remained one of Edwin Forrest's most popular parts in an American play. It was originally written for Augustus A. Addams in 1835 and then revised for Edwin Forrest (Meserve 67). Its melodramatic mode as well as its overtly democratic stance appealed to a largely male and working-class audience and its premiere at the Park Theatre in May 1841 was a major success (JC, Moses' Introduction 433, 436, 438). As in 2 Henry VI, the play focuses on Jack Cade's rebellion in 1450, but Conrad's hero is the exact antithesis of Shakespeare's character.

6 In 2 Henry VI, Cade's legitimacy as a leader is constantly dismissed. A bloody murderer and an illiterate man, he threatens political order and only brings chaos and suffering. On the contrary, Conrad's hero is a virtuous scholar who stands for the American democratic ideals. After a time spent in exile, he comes back to England from Italy under the name of Aylmere. As he witnesses the unbearable living conditions of the English yeomen as well as the cruel actions of the aristocracy, Cade decides to lead a rebellion to free his people. He loses all his beloved ones in the fight. His mother is murdered by Say and his men, his son dies of starvation and his wife Mariamne, overwhelmed with grief, passes away in her husband's arms. Although Cade also dies at the end of the play, his actions have not proved useless, since the king accepts to sign a charter which guarantees the rights of the yeomen.

7 With its anti-British stance, the play is emblematic of a national drama, the aim of which was to champion individual freedom and democracy. This ideological line also influenced some of Conrad's aesthetic choices. In Shakespeare's play, members of the nobility speak in verse most of the time, unlike the commons whose prose is often 
vulgar and syntactically inadequate. Language is therefore meant to reflect a form of social hierarchy and to legitimize it. On the contrary, Conrad's characters all speak in verse. According to Thomas Cartelli, this systematic use of verse was a way to emulate European literary models (Cartelli 37). Yet one may also consider this choice as an openly democratic stance upsetting traditional social distinctions between the ruling classes and the people.

In his preface, Conrad presents his play as a historical and ideological response to Shakespeare's vision of Cade's rebellion in 2 Henry VI. However, his attitude to the playwright's genius is quite ambiguous:

Mr. Malone has satisfactorily demonstrated that the caricature of the leader in the English insurrection of 1450, introduced in Shakspeare's second part of Henry VI., was borrowed from an old play, which, but for his touch of fire, would long since have sunk into oblivion. But it is the attribute of transcendent genius to impart immortality even to the grossest absurdity; and the idea of JACK CADE is now associated, in the popular mind, with all that is vulgar, brutal and barbarous. So general, indeed, is this impression, that the attempt, even in fiction, to render such a character an object of interest, is regarded as a poetical license so presumptuous as to demand apology. The author does not regret a necessity that enables him to correct an historical wrong. (JC, 439)

While clearly responding to the political content of Shakespeare's play, Conrad considers that his ability to turn a caricatured and historically distorted vision of the rebellion into a masterpiece is proof enough of his genius. The preface thus questions Shakespeare's ideological bias in 2 Henry VI while confirming his place in the literary canon. Although he intends to "correct an historical wrong," he then explains that he also incorporated episodes from another rebellion which occurred under the reign of Richard II. In order to justify this conflation of historical events, he argues that "they were provoked by the same wrongs, and were commenced in the same county" (448), but one soon realises that Conrad's aim is not so much to give an accurate account of Cade's rebellion as to provide a melodramatic counter-model to 2 Henry VI which might appeal to Forrest's public.

Several domestic and highly emotional scenes give the play its melodramatic tone. The first time Cade appears in the play, he is accompanied by his wife and his son and is about to knock at his mother's door after several years of exile. This moment of domestic bliss shows that contrary to Shakespeare's play, he is not only presented as a public figure going against the established social and political order, but also as a loving father, husband and son. Several scenes (I.i, for instance) contrast the plight of the yeomen with the harshness of the nobility; at the end of Act II, Cade swears to avenge his mother, who was cruelly murdered by Say's men; in Act IV, as Cade and Mariamne are captured, his wife informs him that their son has died of starvation, but he is denied the right to see the boy's body one last time:

AYLMERE: How fares our boy, my Mariamne? [She averts her face.]

$\mathrm{He}$ is - he is - [She turns, bursts into an agony of tears, and throws herself on his

bosom.]

MARIAMNE: Happy, Aylmere!

AYLMERE: Desolate! desolate! my heart is desolate! [He falls on the shoulder of MARIAMNE and weeps.]

SAY: [Advancing.] Part them. (JC, III, 4, p. 504)

11 Not only do these scenes bring pathos, but they also dismiss the idea according to which Cade is nothing but a murderer and a heartless man. Melodrama -a genre that 
proved to be popular both in the United States and in Europe- is thus both a way to match the audience's expectations and to respond to Shakespeare's treatment of Cade's rebellion.

Cade also embodies a certain number of American ideals and values. A self-reliant man, he manages to escape his social condition through hard work and education. As shown in two passages in the play, his vision of liberty is in line with the democratic ideals of post-revolutionary America ${ }^{3}$ :

AYLMERE: When we are free, Jack Cade

Will back unto his hills, and proudly smile

Down on the spangled meanness of the court,

Claiming a title higher than their highest,-

An honest man - a freeman! (JC, IV, 2, p. 510)

AYLMERE: Liberty gives nor light nor heat itself;

It but permits us to be good and happy.

It is to man, what space is to the orbs,

The medium where he may revolve and shine,

Or, darkened by his vices, fall for ever! (JC, IV, 3, p. 513)

Such reflections on liberty, virtue and morality as well as on the pastoral ideal are reminiscent of Jefferson's political and philosophical thought. The play is therefore as relevant to nineteenth-century America as it is to medieval England and its political content seems to prevail over its dramatic structure and efficiency.

Despite his political response to Shakespeare, Conrad recycled some Shakespearean scenes in Jack Cade. In IV.1, Cade and his wife are held captive by Clifford, who threatens to have the rebel executed if Mariamne refuses to yield to him. The young woman scorns his proposal. The structure of the passage mirrors the dilemma Isabella has to face in Measure for Measure, when Angelo offers to spare Claudio's life if she accepts his advances. Although the ending of Shakespeare's play is less bloody than Conrad's, both women adamantly refuse to yield to a merciless man who usurps his power and show the same unwavering virtue. dying Say:

LACY: [To Aylmere.] You bleed!

SAY: He bleeds? Why then I triumph still!

My steel was venomed and its point is fate. (JC, IV, 3, p. 518)

The episode recalls Laertes' poisoning of the Danish king. The phrase "its point is death" may be interpreted as a metatextual comment on the tragic character of the play's ending. Furthermore, Cade, who wants to avenge his father's untimely death, may evoke Hamlet himself, although his mother is undoubtedly more virtuous than Gertrude.

17 Another striking feature in Conrad's attitude to Shakespeare is the way he recuperated images -hunting metaphors specifically- used by the Elizabethan dramatist in the Henry VI plays. Not only was hunting loaded with political meaning in Renaissance England, but it also re-enacted the historical conquest of the wilderness and was meant to recall the warlike origin of kingship (Marienstras 30, Harrison 72, 74). An aristocratic form of entertainment, it was seen as part of the upbringing of a gentleman (Elyot 82, 84). Hunting and hawking in the Shakespearean trilogy thus define characters socially and establish distinctions that are meant to draw a line between the nobles and the commons. But their function eventually shifts to political issues, stressing Henry's 
failure as a king, and animal or predator images raise social and moral issues (Calderwood, Carr, Morse). Fights, murders and political plots are indeed recurrently depicted in hunting terms: while deer hunting and hawking images suggest the nobility of the characters, references to lower sorts of hunting, such as bird liming, express the social degradation of the English nobility ${ }^{4}$. The medieval and Renaissance social hierarchy being based on the idea that social distinction is tantamount to moral accomplishment, this social disruption is accompanied by moral degradation. Comparing war with a hunt makes it less horrible than it actually is. But as we move forward into the plays, hunting references are increasingly associated with the notions of savagery and slaughter. Once hunting as a metaphor has been associated with ideas of murder and massacre, aristocratic hunters may cross the threshold of savagery and lose what distinguishes them from both the commons and the animal world. Enemies are mercilessly pursued with no consideration for hunting rituals. Hunted animals are thus replaced by humans and England is turned into a shambles. To this extent, hunting in the trilogy can be seen as a response to both humanist criticism and the moral justification of the activity in medieval and Renaissance manuals. Although Shakespeare depicts Cade and his followers as bloodthirsty butchers, he also suggests that the ruling classes behave like beasts and murderers. The Henry VI plays are therefore "a site of struggle" (Dollimore xxii) which simultaneously justifies and subverts social and political order.

In Jack Cade, all noblemen are fond of hunting and the suppression of the rebellion is depicted in such terms to suggest the cruelty of the aristocracy:

SAY: If other game

We start not, we will beat the forest through,

For this same masque, Mortimer. (JC, III, 2, p. 499)

While Say's men are compared to cruel hounds, the people are systematically represented as helpless and innocent prey to the nobility. Cade's words when he confronts Say a few moments before he is arrested are quite revealing: "Hast thou not plundered, tortured, hunted down / Thy fellow-men like brutes?” (JC, IV, 2, p. 503). Conrad therefore disregards Shakespeare's ambivalent treatment of hunting images in the Henry VI plays. Instead of building on images used by the Elizabethan playwright, he simplifies their meaning so that they might serve his political and historical purpose more efficiently. One may venture to argue that Conrad's desire to respond to Shakespeare's vision of the rebellion paradoxically resulted in his failing to grasp the complexity and ambivalence of his predecessor's ideological stance.

George Henry Boker's use of Shakespeare was less politically radical than Conrad's, since he advocated a form of literary continuity between Old Europe and the United States. A prolific playwright, he started his career in the 1850s. Like all the other playwrights of his time, he championed the rise of a national drama:

I remember once being struck with an article, in an old quarterly, on Tom Paine's "Brutus". It seemed to me that, as compared with other modern dramatic works, this tragedy showed well, and was something for an American to feel some pride in. I have no doubt that if a skilful hand would go through the works of Paine, Bird, Conrad, Stone, Willis \&c., an article could be written that the literary world of today sadly needs for its information. (Evans 1980 45-46)

21 Contrary to many of his contemporaries, whose works were openly nationalistic, he argued that the advent of American drama did not require a radical break from European aesthetic and literary models, for drama must transcend national identities, 
reveal man's nature and raise the human soul. This is why he considered that American dramatists should not necessarily use American material but should find inspiration in Ancient, Medieval and Renaissance European culture, if they wanted to obtain any form of literary recognition in the Old World. As he wrote to his friend Richard H. Stoddard:

Read Chaucer for strength, read Spenser for ease and sweetness, read Milton for sublimity and thought, read Shakespeare for all these things and for something else which is his alone. Get out of your age as far as you can. (Gallagher 191)

It is therefore not surprising that he was a fervent admirer of Shakespeare, who, according to a critical tradition which started in the eighteenth century, was regarded as the painter of human nature par excellence (De Grazia 45). In a letter written in 1875, he tried to define the nature of Shakespeare's genius:

You are quite right in your estimate of the character and acquirements of Shakespeare. His was altogether an exceptional nature, and we should not try to measure him by the usual human standards. I believe that Shakespeare was a man of vast and, for his age, of very accurate knowledge, understanding knowledge in its widest sense, as something more and above mere learning. He understood, to the heart of the matter, at a glance that which it might take even superior men years to learn. [...] Before him, the whole cosmos was open, and what he knew was essential truth. After the creation of nature, [...] I think Shakespeare to have been the greatest work that God ever brought before human senses, and the nearest resemblance to Himself, in whose image He created him. (Evans 1980 54-55)

The whole passage is pervaded with the religious rhetoric used in the eighteenth and nineteenth centuries on both sides of the Atlantic to describe the playwright's genius and according to which he was the absolute symbol of universal genius, never to be surpassed. It was from this particular form of rhetoric that Emerson wanted to emancipate in "The American Scholar" (58).

Shakespeare's Henry VIII and Boker's Anne Boleyn focus on Henry VIII's reign, but they do not tell the same story since the latter starts a few years after the ending of the former. They also give two greatly contrasted visions of Henry's character. Shakespeare insisted on the suffering of Queen Katherine, who had to leave the court, but the king was always depicted as a man whose priority was to preserve political stability. Whereas Henry VIII aimed at legitimising the lineage of Queen Elizabeth and contributed to the creation of the Tudor myth, Boker's Henry is an enemy of the arts and of knowledge who has scholars executed and a Machiavelli who scorns and persecutes his people.

Smeaton's fate is also quite revealing of the aristocracy's scorn for the people: a selfmade man born in a poor family, the character has been appointed Groom of the Chamber thanks to his own effort. Norfolk and his followers have him arrested when he prides himself on being Anne's lover. Although they all know this was mere bragging, the man is sentenced to death and Anne is accused of adultery:

SMEATON: My death at this time, or a century hence,

Could make no difference to such mighty lords.

If noble mercy stoops not to the low,

At least be just to me.-

AUNDEL: Cease, whining cur!

The game we are playing is to check the queen;

What care we for a pawn? (AB, III, 4, p. 163) 
In a play written for a nineteenth-century American audience by a Democratic playwright, such lines could only dismiss the legitimacy of the king to the eyes of the public $^{5}$.

While the king neglects his royal duties and noblemen are busy plotting against antagonistic factions, Anne is paradoxically the only character who assumes her political role. This is what her first appearance onstage shows, when she interrupts Henry and Norfolk to discuss religious and diplomatic matters. In order to preserve political stability in the kingdom, she even remains loyal to the crown when she addresses the people before she is executed:

QUEEN: I am come here to die, to yield myself

To the king's will, with all humility.

I pray God save him and extend his reign;

For he has been a gracious prince to you. (AB, V, 6, p. 232-233)

Boker's vision of Henry VIII's reign was radically different from Shakespeare's; yet the playwright recycled some of the major themes developed by the Elizabethan dramatist in his histories - for instance the corrupting effect of power and the illegitimacy of sinful kings. Before he is arrested, Norris denounces the crimes committed by his sovereign:

NORRIS: Do, my liege,

And join assassination to the crimes

That blot your monstrous heart. - I will not hold:

I see you are bent upon destroying me,

And, as a reckless man, I'll know your worst.

$O$, woe to England, when this sinful king,

Grown hard in crime, shall reach the fearful height

That evil points him! (AB, IV, 2, p. 183)

As in Richard III or in Shakespeare's major tragedies, the world is turned upside down. Rochford deplores that "What was our virtue has become our guilt: / Love to the queen is treason to the king" ( $A B, I V, 1$, p. 177). Something is rotten in the kingdom of England.

30 The whole play is indeed pervaded with references to Shakespeare. Although Boker focused on Henry VIII's reign, Anne Boleyn draws more on Richard III than on Shakespeare's last history play. The strategies adopted by those who plot against Anne are quite similar to those used by Richard and his men. Like Richard, Anne's enemies are ready to spread rumours about Elizabeth being a bastard child, or even use "drunken prophecies, libels and dreams" (RIII, I, 1, 33):

NORFOLK: O find me but some little charge,

Less weighty than the air-drawn gossamer -

Some dim tradition, gathered in a dream

Seen by the blaring vision of a drunkard -

Some hearsay mumbled by a maniac's lips,

With fever scorched upon his dying bed. (AB, II, 3, p. 142)

The reference to Shakespeare is all the more obvious since Richard III was Shakespeare's most often produced play in America throughout the nineteenth century (Borman 576). Such references to Richard III are not surprising for they corroborate the idea that Henry VIII is nothing but a merciless and Machiavellian tyrant only driven by his vilest instincts. As Kim C. Sturgess points out, performing a play showing the potential danger of absolute monarchy was a way "for the new American establishment to 
disseminate a political message that reinforced the ideology of republicanism" (Sturgess, 57).

Anne herself recalls some of the female characters of Richard III. In the first act, she becomes aware of the plot against her and wonders whether her fall is not imminent, although she cannot clearly identify the threat:

QUEEN: What means the king by this unwonted coldness?

What means my uncle by his insolence? [...]

Has my life passed the zenith if its glory?

Must I make ready for the gathering clouds

That dog the pathway of a setting sun? ( $A B$ I , 3, p. 128)

This foreboding echoes Queen Elizabeth's words in the third scene of Richard III, when she foresees her impending fall: "Would all were well, but that will never be. / I fear our happiness is at the highest" (I, 3, 36-41). Anne's cursing Jane Seymour and her offspring in Boker's play is also reminiscent of the scenes in which female characters curse the crippled king:

ANNE: Hear me, writhing souls, That minister around sin's ebon throne!

If to these murderers of my heart's dear peace

A child be born, may she, in that sweet time

When infant babble opes all heaven to her,

Feel the cold hand of death draw, day by day,

The clinging spirit from her! May her child

Live in the vexing of a troubled time,

And, issueless, die young! (AB, II, 1, p. 136-7)

In III.2, Viscount Rochford -Anne's brother- relates one of his dreams, in which he and his sister "for years and years, / Had climbed the rundles of a slippery ladder" reaching the sky ( $A B$, III, 2, p. 155). As Anne tried to help her brother, "by the labor tired, / Or dizzy at the awful depth below", the ladder fell apart and each rundle turned into "a ghastly head". All those who were brought down by the Boleyn family (Queen Katherine, Cardinal Wolsey, Cardinal Fisher, Sir Thomas More) and "many a one whose face [he] could not catch" cursed him as they passed him. He then looked up and saw "a dreadful shape, in features like the king, / Tugging and straining with his threatening hand / To hurl [their] ladder to the depths below" (AB, III, 2, p. 156). Three literary sources may be identified in this passage: it may be seen as a nightmarish version of Jacob's dream and as a vertical adaptation of the wheel-of-fortune motif. Although the dream is set in the sky and not on a ship, the "dreadful shape" that causes the fall of Anne and her brother may also be reminiscent of Richard in Clarence's dream, when the villain makes his brother lose his balance and fall overboard. Clarence's drowning in his dream is literalised at the end of the scene, when he is drowned "in the malmseybutt" after being stabbed by his murderers. Similarly, the heads falling in the air foreshadow Rochford and Anne's decapitation. The scene thus appears like an intertextual patchwork which constantly brings the spectator/reader back to its literary sources without making them "swerve" (Bloom 1997 14).

Boker also borrowed elements from Othello to dramatise Henry's feigned jealousy. In IV. 1 , the king and his wife attend a tournament in which Rochford and Norris are opposed. Anne, who is frightened by her husband's violent behaviour, drops her handkerchief, which Norris picks up. Henry immediately interrupts the tournament and accuses Anne of adultery before the court: 
Monstrous, by Jove! What, in our very presence! -

Shameless adulteress! Let the tilt be stopped!

We are as patient as most ill-used men,

But this we cannot bear. Set on, before!

Was ever king thus openly defied? (AB, IV, 1, p. 176) by Iago to convince his master of Desdemona's treason. But contrary to Othello, who has been deceived by Iago and is convinced that his spouse is Cassio's mistress, Henry's jealousy is feigned. Once again, Henry's attitude is reminiscent of Richard III, who has Hastings sentenced to death for treason without any evidence of his guilt. When he mentions the plots against him in Act III, Hastings dares to qualify what his king has said, which proves fatal to him:

HASTINGS: If they have done this thing, my gracious lord RICHARD: 'If', thou protector of this damned strumpet, Tell'st thou to me of 'ifs"? Thou art a traitor,

off with his head! (RIII, III, 4, p. 78-81) deformed son Lanciotto to marry Guido de Polenta's daughter, Francesca. Because of his repulsive appearance, Lanciotto believes Francesca will never love him, all the more so since she is known to be the most beautiful woman in Ravenna. He therefore asks his younger brother Paolo to court the young woman on his behalf, but the young man and Francesca fall in love at first sight and the young woman understands only too late that she is to marry another man. Once back in Rimini, Francesca is introduced to her future husband who complains about her indifferent behaviour towards him. Pepe, the court's jester, warns Lanciotto that his wife will probably be unfaithful to him, but the cripple eventually marries her. When Pepe discovers that she and Paolo are lovers, he immediately informs his master. Mad with rage, the latter stabs the two lovers, although Paolo, who is eaten by remorse, had decided to leave the city.

Boker adapted a well-known story by Dante, but the play's composition and language are mainly indebted to Shakespeare's tragedies. The character of Lanciotto combines several Shakespearean figures: his appearance is reminiscent of Richard III but his bravery, his feats on the battlefield and his jealousy evoke Othello. Some of his lines also echo Hamlet's doubts (Evans 1984 130):

What a fool am I

To bear the burden of my wretched life,

To sweat and toil under the world's broad eye,

Climb into fame, and find myself -0 , what? -

A most conspicuous monster! (FDR, I, 3, p. 262)

Pepe's absence of moral scruples as well as his disregard for social order point to Edmund in King Lear, while his ability to manipulate his master Lanciotto and to arouse his jealousy recalls Iago's strategy. Although the play is adapted from Dante's Inferno, its setting (Medieval Italy) as well as its plot also evoke Romeo and Juliet. The influence of the play is particularly visible in the last scene, in which the two families weep over

Transatlantica, 1 | 2010 
the loss of their children. Unlike the Capulets and the Montagues, the two families intended to enter into an alliance, but Lanciotto insists on their responsibility in the tragic outcome: "Be satisfied with what you see. You two / Began this tragedy, I finished it. Here, by these bodies, let us reckon up / Our crimes together" (FDR, V, 3, p. 473). He echoes the Prince, who blames Romeo and Juliet's relatives for the death of the two "star-cross'd lovers". One may also notice that contrary to Dante's story, no reference is made to Paolo and Francesca's eternal damnation.

In some nineteenth-century American texts, the use of different literary sources is a way for writers to avoid imitation while recycling aesthetic and literary models ${ }^{6}$. As in Rochford's dream, it seems that such intertextual proliferation did not enable Boker to turn Shakespeare's or Dante's verse into his own. On the contrary echoes of canonical texts are not given a new meaning and may be considered a "transmission of some already dead" -or rather petrified and sanctified- "deposit of material" (Ricoeur 68).

While the melodramatic mode of Jack Cade undermines its tragic potential, the ideological content of the play seems to prevail over Conrad's desire to promote an original form of drama in which he might recapture the works of his predecessors. Boker's desire to make his works "timeless" as well as the overwhelming presence of the Elizabethan playwright in his plays prevented him from being more than an epigone. Although he altered his model and sometimes combined references to different plays, his use of the bard was more a form of imitation than of reinvention. Instead of being a "paradigm" providing Boker with a "grammar governing the composition of [a] new [work]", Shakespeare is the canonical reference legitimizing the American playwright's enterprise and seems to be denied "a new existence in the linguistic kingdom" (Ricoeur 69). Conrad and Boker's literary attitudes to Shakespeare proved to be quite different; yet none of them truly questioned his status as a literary icon and a universal genius, never to be surpassed. As they both failed to defamiliarise and to demystify him, they also failed to fully Americanize the English playwright and to make his language "stutter" (Deleuze 55).

\section{BIBLIOGRAPHIE}

ACKERMAN, Alan L., Jr. The Portable Theatre: American Literature and the Nineteenth-Century Stage. Baltimore, London: The Johns Hopkins University Press, 1999.

ALGER, William Rounseville. Life of Edwin Forrest, the American Tragedian. London, Philadelphia: J. B. Lippincott \& Co, 1877.

BANK, Rosemarie K. Theatre Culture in America, 1825-1860. Cambridge: Cambridge University Press, 1997.

BLOOM, Harold. A Map of Misreading [1975]. $2^{\text {nd }}$ ed. New York: Oxford University Press, 2003.

--- The Anxiety of Influence [1973]. $2^{\text {nd }}$ ed. New York, Oxford: Oxford University Press, 1997.

BOKER, George Henry. Plays and Poems, Volume 1. New York: AMS Press, Inc., 1967.

Transatlantica, 1 | 2010 
BORMAN, Gerald Martin ed. The Oxford Companion to American Theatre. New York, Oxford: OUP, 1984.

BRISTOL, Michael. Shakespeare's America, America's Shakespeare. London, New York: Methuen, 1990.

CALDERWOOD, James. L. "Shakespeare's evolving imagery: 2 Henry VI." English Studies - A Journal of English Letters and Philology. Ed. R. W. Zandvoort. Vol 48 (1967): 481-493.

CARR, Virginia, M. “Animal imagery in 2 Henry VI.” English Studies - A Journal of English Language and Literature. Ed. R. Derolez. Vol 53 (1972): 408-412.

CARTELLI, Thomas. Repositioning Shakespeare. National Formations, Postcolonial Appropriations. London, New York: Routledge, 1999.

CONRAD, Robert. “Jack Cade." Representative Plays by American Dramatists. Ed., Montrose J. Moses. New York: E. R. Dutton \& Company, 1925.

DE GRAZIA, Margreta. Shakespeare Verbatim: The Reproduction of Authenticity and the 1790 Apparatus. Oxford: The Clarendon Press, 1991.

DELEUZE, Gilles. Essays Critical and Clinical [1993]. Trans. D. W. Smith and M. A. Greco. London, New York: Verso, 1998.

DOLLIMORE, Jonathan. Radical Tragedy. Religion, Ideology and Power in the Drama of Shakespeare and His Contemporaries [1984]. Durham: Duke University Press, 1989.

DUNN, Esther Cloudman. Shakespeare in America. New York: The Macmillan Company, 1939.

ELYOT, Sir Thomas. The Boke Named The Governor. Ed. Donald W. Rude. New York and London: Garland Publishing, Inc., 1992.

EMERSON, Ralph Waldo. Essays and Lectures. Ed. Joel Porte. New York: Literary Classics of the United States, 1983.

EVANS, Oliver H. "Four letters from George Henry Boker to John Seely Hart." Pennsylvania Magazine of History and Biography. No.104 (1980): 39-57.

--- George Henry Boker. Boston: Twayne Publishers, 1984.

GALLAGHER, Kent J. “The Tragedies of George Henry Boker. The Measure of American Romantic Drama.” ESQ. No. 20 (1974): 187-215.

HARRISON, Robert Pogue. Forests - The Shadow of Civilization. Chicago and London: The University of Chicago Press, 1992.

LEVINE, Lawrence. Highbrow / Lowbrow: The Emergence of Cultural Hierarchy in America. Cambridge: Harvard University Press, 1988.

LUDOT-VLASAK, Ronan. "Transactions en eaux troubles: résurgences de la voix shakespearienne dans Moby-Dick.” LISA. VII:2 (2009): 104-116. http://lisa.revues.org/index299.html

MARIENSTRAS, Richard. New Perspectives on the Shakespearean World. Cambridge: Cambridge University Press / Paris: Editions de la Maison des Sciences de l'Homme, 1985.

MESERVE, Walter J. Heralds of Promise: The Drama of American People During the Age of Jackson. New York, Westport: Greenwood Press, 1986.

MORSE, Ruth. "Unfit for human consumption: Shakespeare's unnatural food.” Deutsche Shakespeare-Gesellshaft West Jahrbuch. Bochum: Verlag Ferdinand Kamp GmbH \& Co, KG, 1983, 125-149. 
MOSES, Montrose Jonas, Brown, John Mason, eds. The American Theatre as Seen by its Critics. New York: W. W. Norton \& Company, Inc., 1934.

RICOEUR, Paul. Time and Narrative [1983].Trans. K. McLaughlin and D. Pellauer. Chicago: The University of Chicago Press, 1990.

SHAKESPEARE, William. The Second Part of King Henry VI. Ed. Michael Hattaway. Cambridge: CUP, 1991.

--- Othello. Ed. M. R. Ridley. London and New York: Routledge, 1992 (1958).

--- The Tragedy of King Richard III. Ed. John Jowett. Oxford and New York: OUP, 2000.

--- Romeo and Juliet. Jill L. Ed. Levenson. Oxford and New York: OUP, 2000.

STURGESS, Kim C. Shakespeare and the American Nation. Cambridge: CUP, 2004.

\section{NOTES}

1. Thirty-one people were killed in the riot, after the militia was called out. For more information about the Astor Place riot, see Ackerman (37) and Meserve (86).

2. As the title of Michael Bristol's book -Shakespeare's America - America's Shakespeare-indicates, "the interpretation of Shakespeare and the interpretation of American popular culture are two mutually determining practices" (Bristol 3). The verb "shakespearize" is used by Ralph Waldo Emerson in "The American Scholar," an essay in which he calls for the advent of an American literature that breaks from European literary models: "The English dramatic poets have Shakspearized now for two hundred years" (58).

3. Edwin Forrest was a staunch democrat and delivered a speech on the occasion of the $62^{\text {nd }}$ anniversary of the Declaration of Independence, a celebration held under the auspices of the Democratic Party (Alger 339).

4. For instance, Suffolk and Beaumont use images related to utilitarian forms of hunting when they have Gloucester arrested (III, 1, 55 and III, 1, 252-256), and his wife metaphorically becomes a bird limed by Suffolk in I.3.

5. Yet the play was never performed.

6. It is the case for instance with Melville, who not only combines Biblical, Miltonian and Shakespearean echoes in Moby-Dick, but also merges references from several Shakespearean plays, thus making his sources difficult to identify (Ludot-Vlasak 111). My contention is that such a strategy enabled Melville to defamiliarise his literary models and to give them a new meaning.

\section{RÉSUMÉS}

Cet article s'intéresse aux modalités selon lesquelles deux dramaturges américains du XIX ${ }^{\mathrm{e}}$ siècle - Robert Conrad (1810-1848) et George Henry Boker (1823-1890) - cherchent à s'approprier l'œuvre de Shakespeare. Dans Jack Cade, Conrad propose un contre-modèle mélodramatique à 2 Henri VI. La pièce révèle l'incapacité de l'auteur à saisir toutes les ambivalences idéologiques et morales de l'œuvre de son prédécesseur, mais aussi à remettre en cause la notion de génie shakespearien. L'approche de Boker s'avère beaucoup plus révérencieuse à l'égard de 
Shakespeare. Dans Francesca da Rimini et Anne Boleyn, l'écrivain transforme son modèle et combine des références à différentes pièces, mais il n'en reste pas moins un épigone. Si les deux auteurs ne réinventent pas l'œuvre du dramaturge élisabéthain, c'est qu'ils ne parviennent ni à remettre en question le statut d'icône littéraire de ce dernier, ni à le « défamiliariser ».

This article explores the literary responses of two nineteenth-century American playwrights to Shakespeare: Robert Conrad (1810-1848) and George Henry Boker (1823-1890). While Conrad aimed at providing a melodramatic counter-model to 2 Henry VI in Jack Cade, he failed to grasp Shakespeare's ambivalent stance and to challenge his figure as a symbol of literary genius. Boker's less radical and more reverential approach in Anne Boleyn and Francesca da Rimini prevented him from being more than an epigone. Although he altered his model and sometimes combined references to different plays, his use of Shakespeare was more a form of imitation than of reinvention. Conrad and Boker's literary attitudes to the Bard proved to be quite different, but they both failed to defamiliarise him and to truly question Shakespeare as a literary icon.

\section{INDEX}

Keywords : American drama, George Henry Boker, intertextuality, nineteenth-century literature, Robert Conrad, Shakespeare

Mots-clés : George Henry Boker, intertextualité, littérature du XIXe siècle, Robert Conrad, Shakespeare, théâtre américain

\section{AUTEUR}

\section{RONAN LUDOT-VLASAK}

Université Grenoble 3 